Copying. This journal is registered with the Copyright Clearance Center, 27 Congress Street, Salem, Mass. 01970. Organizations in the USA who are also registered with C.C.C. may therefore copy material (beyond the limits permitted by sections 107 and 108 of the US copyright law) subject to payment to C.C.C. of the per-copy fee of $\$ 5.00$. This consent does not extend to multiple copying for promotional or commercial purposes. Code 0007-1145/92 $\$ 5.00+.00$.

ISI Tear Sheet Service, 3501 Market Street, Philadelphia, Pennsylvania 19104, USA, is authorized to supply single copies of separate articles for private use only.

For all other use, permission should be sought from Cambridge or the American Branch of Cambridge University Press.

The Proceedings of the Nutrition Society, published by the Cambridge University Press, in part record meetings of the Symposium type, at which experts in a particular field are invited by Council to make contributions on specific parts of it and at which general discussion follows these invited contributions. The contributions will be published in extenso; such summaries of the ensuing discussions as circumstances warrant may also be published. The Society also holds scientific meetings at which papers are communicated by members and others on original work carried out by them. It is proposed at present to publish summaries of the papers read at each meeting, each communication being recorded in the Society's Proceedings by means of an abstract not exceeding in length 400 words or the equivalent space in print. The Proceedings are published three times a year.

The subscription to the Proceedings is $£ 103.00$ net (US $\$ 204.00$ in USA and Canada). Single issues are $£ 36.00$ (US $\$ 71.00$ in the USA and Canada) each; postage extra.

\begin{tabular}{|c|c|c|}
\hline Andrieux, $\mathrm{C}$. & 489 & Gibney, M. J. \\
\hline Avery, P. J. & 355 & $\begin{array}{l}\text { Gill, M. } \\
\text { Goni, I. }\end{array}$ \\
\hline Bates, C. J. & 445 & Goodlad, J. S. \\
\hline Beynen, A. C. & 379 & Gregersen, S. \\
\hline Bouchet, B. & 489 & \\
\hline Bravo, L. & 463 & $\begin{array}{l}\text { Hermansen, K. } \\
\text { Hocking, P. M. }\end{array}$ \\
\hline Cheeseman, K. H. & 457 & Hunter, B. \\
\hline Cowen, T D. & 445 & Hunter, R. A. \\
\hline Delahaye Pacheco, E. & 489 & Kelly, F. J. \\
\hline Den Bieman, $\mathrm{M}$. & 379 & Kennedy, $\mathrm{H}$. \\
\hline Dewhurst, R. J. & 345 & \\
\hline Dhanoa, M. S. & 305 & Leibholz, J. \\
\hline Eagles, J. & 411 & Mathers, J. C. \\
\hline Edwards, H. M. & 421 & McDonald, G. S. A. \\
\hline Evans, P. H. & 445 & Meijer, G. W. \\
\hline Fairweather-Tait, S. J. & 411 & Parker, D. S. \\
\hline Fox, T. E. & 411 & Peters, T. J. \\
\hline Gallant, D. & 489 & Rasmussen, $\mathrm{O}$. \\
\hline
\end{tabular}

\title{
INDEX OF AUTHORS
}

\begin{tabular}{r|lr}
501 & Rowland, G. & 421 \\
305,319 & & \\
463 & Safavi, M. & 457 \\
475 & Sanders, A. M. & 421 \\
371 & Saunderson, C. L. & 391 \\
& Saura-Calixto, F. & 463 \\
371 & Seal, C. J. & 355 \\
391 & Sidhar, S. & 437 \\
501 & Simpson, R. J. & 437 \\
337 & Sissons, J. & 319 \\
& Southgate, D. A. T. & 303 \\
457 & Szylit, O. & 489 \\
411 & & \\
& Thiago, L. R. L. & 305,319 \\
401 & & 379 \\
& Van der Wouw, M. J. A. & 379 \\
475 & Van Lith, H. A. & 379 \\
501 & Van Tintelen, G. & 379 \\
379 & Van Zutphen, L. F. M. & \\
& & 345 \\
355 & Webster, A. J. F. & 411 \\
437 & Wharf, S. & \\
371 & &
\end{tabular}




\section{CONTENTS}

\section{Editorial}

The ethics of peer review. D. A. T. Southgate

\section{Effects of Diet on Food Intake of Cattle}

Studies of method of conserving grass herbage and frequency of feeding in cattle. 1. Voluntary feed intake, digestion and rate of passage. L. R. L. Thiago, M. Gill and M. S. Dhanoa

Studies of method of conserving grass herbage and frequency of feeding in cattle.

2. Eating behaviour, rumen motility and rumen fill. L. R. L. Thiago, M. Gill and J. Sissons

\section{Energy Metabolism}

The effect of the $\alpha_{2}$-adrenergic agonist, guanfacin, on the energy metabolism of steers fed on low-quality-roughage diets. R. A. Hunter

\section{Metabolic Effects of Diet}

Effects of diet, level of intake, sodium bicarbonate and monensin on urinary allantoin excretion in sheep. R. J. Dewhurst and A.J.F. Webster

The effect of forage and forage-concentrate diets on rumen fermentation and metabolism of nutrients by the mesenteric-and portal-drained viscera in growing steers. C. J. Seal, D. S. Parker and P. J. Avery

Influence of the amount of starch on the glycaemic index to rice in non-insulindependent diabetic subjects. $O$. Rasmussen, $S$. Gregersen and K. Hermansen

Influence of amount of dietary fat and protein on esterase-1 (ES-1) activities of plasma and small intestine in rats. H. A. Van Lith, G. W. Meijer, M. J. A. Van der Wouw, M. Den Bieman, G. Van Tintelen, L. F. M. Van Zutphen and A. C. Beynen

Amino Acid Metabolism

Muscle protein degradation assessed by $\mathrm{N}^{\mathrm{t}}$-methylhistidine excretion in mature White Leghorn, dwarf broiler and normal broiler males maintained on either lowor high-protein diets. P. M. Hocking and C. Linda Saunderson

The availability of lysine in diets for pigs: comparative methodology. Jane Leibholz $401-410$

\section{Absorption of Inorganic Nutrients}

Zinc absorption in adult men from a chicken sandwich made with white or wholemeal bread, measured by a double-label stable-isotope technique. Susan J. Fairweather-Tait, Thomas E. Fox, S. Gabrielle Wharf, John Eagles and Hugh Kennedy

\section{For Index of Authors see inside back cover}

\section{CAMBRIDGE UNIVERSITY PRESS}

The Pitt Building, Trumpington Street, Cambridge CB2 1RP

40 West 20th Street, New York, NY 10011-4211, USA

10 Stamford Road, Oakleigh, Victoria 3166, Australia

Printed in Great Britain by the University Press, Cambridge 